\title{
General practice consultation in childhood in The Netherlands: sociodemographic variation
}

\author{
Marc A Bruijnzeels, Johannes C van der Wouden, Marleen Foets
}

Consultation with a GP is the point of entry into the Dutch health care system. We studied the sociodemographic determinants of GP consultation rates for children. The determinants that are examined are age, gender, socioeconomic status, health insurance, degree of urbanisation, and ethnicity.

Methods: We used data for children 0 to 14 years from the Dutch national survey of morbidity and interventions in general practice, carried out by The Netherlands Institute of Primary Health Care (NIVEL) between April 1987 and March $1988 .^{2}$ A random, non-proportionally stratified sample of 161 GPs was drawn. All persons listed in the participating practices provided basic sociodemographic data. The 161 GPs (103 practices) were divided into four groups of approximately 40 GPs. Each group registered every contact between the practice and patient during three consecutive months and in this way one whole year was covered. Registration was episodeoriented. Consultations concerning the same health problem were grouped into episodes of care. We considered only episodes in which the first contact took place within the registration period for a new or relapse problem. The diagnosis considered in this study is the diagnosis made in the last contact registered for the episode. To assess the nature of the problem the episode diagnoses are grouped into clusters. The clusters of interest are acute somatic complaints, infections, chronic problems, and traumas.

We compared odds ratios (OR) resulting from bivariate logistic regressions and a multivariate logistic regression to assess the contributions of all sociodemographic determinants. In addition, the possible interaction effects between socioeconomic status, insurance coverage, ethnicity, and degree of urbanisation were evaluated.

Results: The table shows that $32 \%$ of all children consulted the GP at least once during three months. Younger children, boys, children from lower socioeconomic strata, children insured through the sick funds, children living in the larger cities, and non-Dutch children consulted the GP more often. The association between ethnicity and consultation rate, however, disappears in a multivariate analysis. For three of four different diagnosis clusters the relations show the same direction with different magnitudes. For trauma, older children and children in smaller cities yield higher consultation rates.

The analysis including a possible interaction effect shows that the largest difference in consultation rates existed between children who were insured through the sick funds and lived in the larger cities (39\%) on one hand and children who were privately insured and lived in the smaller cities $(26 \%)$ on the other. Within these two groups children whose socio- \\ Correspondence to: Mr M A Bruijnzeels. Accepted for publication 1995;49:532-533}

Percentages, bivariate, and multivariate odds ratios (OR) of children who consulted the GP for all episodes and in relation to morbidity category by sociodemographic factors

\begin{tabular}{|c|c|c|c|c|c|c|c|}
\hline \multirow[t]{2}{*}{ Sociodemographic factor } & \multicolumn{3}{|c|}{ All episodes (32\%) } & \multicolumn{4}{|c|}{ Morbidity category (multivariate $O R$ ) } \\
\hline & $\%$ & $\begin{array}{l}\text { Bivariate } \\
\text { OR }\end{array}$ & $\begin{array}{l}\text { Multivariate } \\
O R\end{array}$ & $\begin{array}{l}\text { Acute somatic } \\
(8.6 \%)\end{array}$ & $\begin{array}{l}\text { Infections } \\
\text { complaints } \\
(20.9 \%)\end{array}$ & $\begin{array}{l}\text { Chronic } \\
\text { problems } \\
(10.1 \%)\end{array}$ & $\begin{array}{l}\text { Traumas } \\
(4.3 \%)\end{array}$ \\
\hline Age (reference category: $0-4(y)$ & 43 & 1.00 & & & & & \\
\hline $\begin{array}{l}5-9 \\
10-14\end{array}$ & 31 & $0.60^{* *}$ & $0.60^{* *}$ & $0.92 *$ & $0.55^{* *}$ & $0.64^{* *}$ & $0.98 \mathrm{NS}$ \\
\hline $\begin{array}{l}10-14 \\
\text { Gender (reference category: Boys }\end{array}$ & $\begin{array}{l}24 \\
32\end{array}$ & $\begin{array}{l}0.42^{* *} \\
1.00\end{array}$ & $0.42^{* *}$ & $0.74^{* *}$ & $0.26^{* *}$ & & \\
\hline Girls & 33 & $1.04^{*}$ & $1.04 *$ & $1.19^{* *}$ & $1.03 \mathrm{NS}$ & $0.99 \mathrm{NS}$ & $0.81^{* *}$ \\
\hline $\begin{array}{l}\text { Socioeconomic status (reference category: high) } \\
\text { Low/middle }\end{array}$ & 29 & 1.00 & & & & & \\
\hline $\begin{array}{l}\text { Low/middle } \\
\text { Health insurance (reference category: private) }\end{array}$ & 33 & $1.24 * *$ & $1.15^{* *}$ & $1.11^{*}$ & $1.22^{* *}$ & $1.07 \mathrm{NS}$ & $1.12 \mathrm{NS}$ \\
\hline $\begin{array}{l}\text { Health insurance (reference category: private) } \\
\text { Sick funds }\end{array}$ & 28 & 1.00 & & & & & \\
\hline $\begin{array}{l}\text { Sick funds } \\
\text { Urbanisation (reference category: <50 000) }\end{array}$ & $\begin{array}{l}35 \\
31\end{array}$ & $\begin{array}{l}1.40^{* *} \\
1.00\end{array}$ & $1.31^{* *}$ & $1.34^{* *}$ & $1.27^{* *}$ & $1.25^{* *}$ & $1.20^{* 4}$ \\
\hline $\begin{array}{l}\text { Urbanisation (reference category: }<50000 \text { ) } \\
>50000 \text { inhabitants }\end{array}$ & 36 & $1.21^{* *}$ & $1.23^{* *}$ & $1.12^{* *}$ & $1.25^{* *}$ & $1.14^{* *}$ & $0.85^{*}$ \\
\hline Ethnicity (reference category: Dutch) & 32 & 1.00 & & & & & \\
\hline Non-Dutcht & 36 & $1.14^{* *}$ & 0.99 NS & $0.99 \mathrm{NS}$ & $1.04 \mathrm{NS}$ & $1.00 \mathrm{NS}$ & $0.86 \mathrm{NS}$ \\
\hline
\end{tabular}

NS, not significant; ${ }^{*} p<.05 ;{ }^{* *} p<.01$
tA child is considered non-Dutch if either the child or one of its parents is born in Turkey, Morocco, Surinam or the Netherlands Antilles or its has one of these nationalities. 
economic status was low consulted more often than those whose status was high socioeconomic.

Conclusions: Three conclusions may be drawn from this study. Firstly, there are relatively large differences in consultation rates between different subgroups. The consultation rate for children who live in a large city and are insured through the sick funds is 1.5 times that of children who live outside the large cities and who are privately insured. This difference has implications not only for the children but also for the burden on the health care system in different areas. GPs who work in socioeconomically deprived areas in larger cities are consulted more often for children than their colleagues in better off areas.

Secondly, if the relation between ethnicity and consultation rate is studied multivariately, the effect of ethnicity disappears. In The Netherlands allochthonous children consult the GP more often than all autochthonous children, but not more often than autochthonous children who live under the same socioeconomic and urban circumstances. The cultural differences between Dutch and autochthonous children do not affect their consultation rates. ${ }^{3}$

Thirdly, the subdivision into morbidity categories shows some small deviant relations. This subdivision seems relatively unimportant, when studying GP consultation. ${ }^{4}$

1 Starfield B, Berg BJ van den, Steinwachs DM, Katz HP, Horn SD. Variations in utilization of health services by children. Pediatrics 1979;63:633-41.

2 Foets $M$, Velden J van der, Bakker $\mathrm{D}$ de. Dutch national survey of general practice. A summary of the survey design. Utrecht: of general practice. A summary of the survey design. Utr.

3 Senior PA, Bophal R. Ethnicity as a variable in epidemiological research. BMf 1994;309:327-30

4 McCue Horwitz S, Morgenstern H, Berkman LF. The use McCue Horwitz S, Morgenstern H, Berkman LF. The use
of pediatric medical care: a critical review. $f$ Chron Dis 1985;38:935-45. 